\title{
EKONOMI-TANDA:
}

\section{ANALISIS AWAL TENTANG SUBYEKTIVISME DALAM TEORI HARGA}

\author{
Tarli Nugroho \\ Fakultas Ekonomi Universitas Proklamasi 45, Yogyakarta
}

\begin{abstract}
The purpose of this article is to reveal that the price theory, as will be described later, no longer are objective, or rely on objective factors as commonly claimed by economics, but has been completely rely on subjectivity. What is the mean of subjectivity? This article attempts to outline complexity those theoretical issues.
\end{abstract}

Key Words: price theory, subjectivity, semiotics

\section{PROBLEM DALAM TEORI HARGA}

Kenapa harga sebungkus rokok Djarum Coklat sama dengan harga tiga butir telur ayam kampung?' Pertanyaan ini bisa menjadi pembuka jalan untuk mengurai kenapa sebuah produk dihargai dengan harga tertentu dan produk lainnya dihargai dengan harga tertentu lainnya. Teori harga (price theory), salah satu bab terpenting dari ilmu ekonomi, merupakan teori yang paling bertanggung jawab untuk menjelaskan pertanyaan tadi. Pada konsep harga pula kita akan menemukan jawaban kenapa suatu barang bisa dipertukarkan dengan barang lainnya dengan perbandingan jumlah yang tertentu. Harga menghubungkan berbagai sumber daya yang beraneka dan tersebar ke dalam satu sistem yang terintegrasi. ${ }^{2}$

Menurut Zimmerman, teori harga selalu menjadi inti pembicaran sepanjang sejarah pemikiran ekonomi dari klasik hingga kontemporer. Semua masalah ekonomi selalu dianalisis sebagai kompleksitas permintaan

\footnotetext{
${ }^{1}$ Di Pasar Beringharjo, Yogyakarta, harga satu butir telur ayam kampung adalah Rp2.000, dan harga sebungkus Djarum Coklat adalah Rp6.500.

${ }^{2}$ Bandingkan Harry Townsend (ed.), Price Theory: Selected Readings (London: Penguin, 1973), hal. 8; dan Oskar Lange, "On the Economic Theory of Socialism" dalam Oskar Lange dan Fred M. Taylor (Edited by Benjamin E. Lippincott, On the Economic Theory of Socialism (New York: McGraw-Hill, 1966), hal. 60. Tulisan Lange, yang disebut terakhir, juga dimuat dalam Townsend (ed.), sebagai Bab 2 dari buku itu. Untuk uraian selanjutnya, kutipan atas karya Lange akan menggunakan buku yang disunting Lippincott (1966).
} 
(demand) dan penawaran (supply), dimana teori harga akan menerangkan dengan moda produksi bagaimana, jumlah upah pekerja seberapa, serta menentukan seberapa besar jumlah barang yang harus diproduksi agar dapat dikonsumsi oleh subjek-subjek ekonomi (Zimmerman, 1955: 209). Apa yang dikemukakan Zimmerman, juga diungkap oleh George Soule. Menurut Soule, teori harga dan nilai selalu merupakan inti sari dalam teori ekonomi. Bahkan, para ahli ekonomi "murni" pada dasarnya hanya membatasi ketertarikan mereka pada soal nilai dan harga ini (Soule, 1955: 105). Demikian juga dengan Schumpeter, yang berpendapat bahwa pembentukan harga merupakan sifat khas dari ilmu ekonomi dan bahwa semua peristiwa ekonomi dapat dimengerti dalam rangka pembentukan harga (Schumpeter, 1963: 101). Hal itu diungkapkan Schumpeter dalam tulisannya mengenai Carl Menger (1840-1921). Lebih jauh, sebagaimana yang dibayangkan oleh Menger dan pemikir Neoklasik lainnya, banyak ekonom sebenarnya berpandangan bahwa yang dimaksud dengan sistem ekonomi sebenarnya tiada lain adalah "sistem harga yang saling bergantungan".

Selama lebih dari satu abad, hingga pertengahan abad keduapuluh, teori harga telah menjadi pusat perhatian para sarjana ekonomi. Hanya saja, munculnya pembagian kebidangan ilmu ekonomi, dari yang tadinya utuh lalu menjadi mikro dan makro, telah membuyarkan fokus perhatian terhadap teori harga. Teori harga memang masih menjadi fokus penting dalam bidang kajian ekonomi mikro (mircoeconomics). Tapi dalam kajian ekonomi makro (macroeconomics), pendapatan nasional merupakan isu utamanya.

Namun, meskipun demikian, bagi mereka yang peka terhadap kerangka teoritis ilmu ekonomi, konsep-konsep penting dalam ilmu ekonomi makro pada dasarnya adalah agregasi dari konsep-konsep mikro, dimana secara keseluruhan masih terhubung dengan teori harga. Sedemikian menyegalanya teori harga, hingga Schumacher dengan gusar menyebut bahwa ilmu ekonomi telah membuat segala sesuatu seolah memiliki harga, sesuatu yang disebutnya sebagai sebentuk "kemustahilan yang [sayangnya] logis (logical absurdity)" (Schumacher, 1975: 45-6). ${ }^{3}$

Secara teoritis, teori harga merupakan titik temu (rallying point) antara teori perilaku konsumen (yang memunculkan permintaan, demand), dengan teori perilaku produsen (yang memunculkan penawaran, supply), dan teori produksi (yang memunculkan alokasi sumber daya). Harga, menurut

\footnotetext{
${ }^{3}$ Apa yang dilontarkan Schumacher sebenarnya merupakan kritik terhadap ekonomisme, suatu keyakinan bahwa nilai segala benda bisa dikonversikan ke dalam bentuk uang. Bandingkan Fritjof Capra, Kearifan Tak Biasa: Percakapan dengan Orang-orang Luar Biasa (Yogyakarta: Bentang, 2002), hal. 270. Lihat keseluruhan percakapan Capra dengan Hazel Handerson. Gagasan ekonomi Handerson sebenarnya sangat dipengaruhi oleh gagasan ekonomi dan filsafat Schumacher.
} 
Mubyarto (1987) adalah hasil akhir dari bekerjanya sistem pasar. Namun, sebagaimana akan kita lihat, dan lebih jauh akan diuraiakan dalam pembahasan, teori harga sebagaimana yang diajarkan oleh teori ekonomi neoklasik (mainstream economics, atau kini disebut juga neoliberal), semakin mengimputasi dirinya dari hubungannya dengan sumber daya. Dengan kata lain, ia kini lebih banyak berurusan hanya dengan perilaku konsumen dan perilaku produsen, daripada antara keduanya dengan teori produksi. Bahkan, lebih jauh, perilaku konsumen kemudian menjadi determinan bagi proses terbentuknya harga di pasaran.

Teori harga sebagai bagian pokok dari teori ekonomi mengalami perkembangan terus-menerus. Dalam buku teks yang disusun Hirshleifer (1985), Samuelson dan Nordhaus (1995), Varian (1996), Nicholson (2002), Mankiw (2006), serta Case dan Fair (2007), yang bisa dianggap sebagai representasi standar buku teks ilmu ekonomi arus utama (mainstream economics),${ }^{4}$ teori harga telah memapankan dirinya sebagai terusan pikiran dari apa yang dalam buku sejarah pemikiran ekonomi disebut sebagai Mazhab Austria. Jika menyimak pohon kekerabatan ilmu ekonomi yang dibuat Samuelson, tiap mazhab pemikiran ekonomi sebenarnya merumuskan teori harganya sendiri-sendiri. Dari sejak aliran Merkantilis (Thomas Mun, Gerard de Malynes, Charles Davenant, Jean-Baptiste Say, dan William Petty di abad ke-17 dan 18), Mazhab Fisiokrat (Francois Quesnay dan Robert Jacques Turgot di abad ke-18), Klasik (Adam Smith, David Ricardo, dan Thomas Robert Malthus, di abad ke-18), Sosialis/Marxis (Hegel, Karl Marx, Friedrich Engels, dan Ludwig Feurbach, di abad ke-19), hingga teori ekonomi Neoklasik (Leon Walras, Carl Menger, Stanley Jevons, dan Alfred Marshall, di abad ke-19). Mazhab Austria adalah yang memberi warna paling kuat dalam teori ekonomi neoklasik.

Meskipun buku-buku teks ekonomi kontemporer biasanya paling jauh hanya menyebut Marshall (1842-1924) sebagai titik simpul teori ekonomi neoklasik, apa yang dilakukan Marshall sebenarnya hanya meringkus gagasan-gagasan yang telah dikemukakan Leon Walras (1834-1910) dan Carl Menger (1940-1921). ${ }^{5}$ Walras dan Menger, bersama dengan Eugen von Bohm-Bawerk (1851-1914), merupakan teoritisi besar yang pemikiran mereka

\footnotetext{
${ }^{4}$ Nama-nama yang disebut adalah alumni dan/atau merupakan pengajar di Harvard University, University of California (Berkeley dan Los Angeles), Yale University, dan Massachusetts Institute of Technology, yang secara faktual bisa disebut sebagai universitas-universitas paling berpengaruh, bukan hanya di Amerika, melainkan juga di dunia, baik dalam kedudukan keilmuannya secara umum maupun terutama dalam hubungannya dengan produksi gagasan di wilayah ilmu ekonomi.

${ }^{5}$ Bandingkan Joseph A. Schumpeter, Sepuluh Sarjana Ekonomi Terkemuka: Dari Marx sampai Keynes (Jakarta: Bhratara, 1963), hal. 92; Paul-Heinz Koesters, Tokoh-Tokoh Ekonomi Mengubah Dunia (Jakarta: Gramedia, 1988), terutama Bab 5; L.J. Zimmerman, Sedjarah Pendapat-Pendapat tentang Ekonomi (Bandung: W. van Hoeve, 1955), terutama Bab 6 dan 9; dan George Soule, Ideas of the Great Economists (New York: Mentor Book, 1955), hal. 102.
} 
kini disebut sebagai pemikiran Mazhab Austria. Di tangan Walras dan Menger itulah, serta seorang ekonom Inggris yang hidup sezaman dengan mereka, Stanley Jevons (1835-1882) apa yang kini kita kenal sebagai teori utilitas diramu menjadi sebuah gagasan “ilmiah". Tentu saja ketiganya, terutama Walras dan Jevons, berhutang gagasan terhadap Herman Henrich Gossen (1810-1858), seorang ekonom jenius yang pikirannya merupakan batu pijakan penting bagi buah pikiran mereka.

Namun, bukan maksud artikel ini untuk melakukan tinjauan ulang atas berbagai teori yang berkembang untuk kemudian mengambil kesimpulan atas perkembangan-perkembangan yang telah terjadi tersebut. Maksud dari artikel ini adalah untuk mengungkapkan bahwa teori harga, sebagaimana akan diuraikan kemudian, tak lagi bersifat objektif, atau bertumpu pada faktor-faktor obyektif sebagaimana yang lazim diklaim oleh ilmu ekonomi, melainkan telah sepenuhnya bertumpu pada subyektivitas. Apa maksud dari subyektivitas? Artikel ini mencoba menguraikan serba sederhana persoalan teoritis yang rumit tersebut.

\section{PRODUK DAN PENCITRAAN-PRODUK}

Perang kualitas produk telah usai. Kalimat itu merupakan lead sebuah artikel di lembaran sisipan sebuah media ibukota yang sedang meliput ajang brand award, sebuah acara pemeringkatan merek-merek terkenal dan termahal yang diadakan oleh sebuah lembaga riset pemasaran di Jakarta (Koran Tempo, 31 Agustus 2005; SWA, No. 04/XVII/2001). Sekilas, meski terkesan provokatif, pernyataan tersebut sebenarnya hanya memindai apa yang sedang berkembang di sekitar kita apa adanya. Dan begitulah memang yang sedang terjadi. Ketika teknologi bisa membuat produk menjadi seragam, maka berakhirlah perang kualitas. Para pemain baru bisa dengan mudah meniru habis-habisan produk jawara pasar (market leader). Dalam produk makanan, misalnya, bukan hanya kemasan (packaging) yang bisa sama, melainkan juga resepnya (ingredients). Jika diteliti dengan cermat, perbedaan antara satu produk dengan produk lainnya, sebenarnya sangat kecil sekali, untuk tidak menyebutnya tidak ada sama sekali.

Lantas, jika begitu, apa yang membedakan satu produk dengan yang lainnya, sehingga ada produk-produk yang berhasil meraih pangsa pasar besar, sementara produk lainnya hanya bermain di ceruk pasar yang kecil?

Citra dan reputasi merek ternyata adalah pertimbangan utama bagi konsumen dalam memilih produk yang akan dikonsumsinya. Beberapa uji pasar telah membuktikan hal ini. Dalam sebuah blind test produk mie instan, sebuah produk mie baru sebenarnya lebih disukai ketimbang mie yang kebetulan menjadi market leader. Ketika diluncurkan, produk tersebut kemudian memang berhasil mencuri pangsa pasar. Hanya saja, dia tetap tak bisa menggeser posisi nomor satu dengan selisih penguasaan pasar (market 
share) yang juga tetap jauh. Tentu ini memunculkan pertanyaan, bagaimana bisa sebuah produk yang rasanya lebih disukai oleh konsumen ternyata tidak bisa merebut pasar pesaingnya? Sebabnya, meski konsumen berpendapat mie tersebut lebih enak daripada mie yang jadi penguasa pasar, begitu mie tadi dibalut oleh kemasan dan dilabeli merek tertentu, preferensi konsumenpun berubah. Inilah yang dalam pemasaran disebut sebagai era perang citra, dimana merek dan iklan menjadi senjata penjualan.
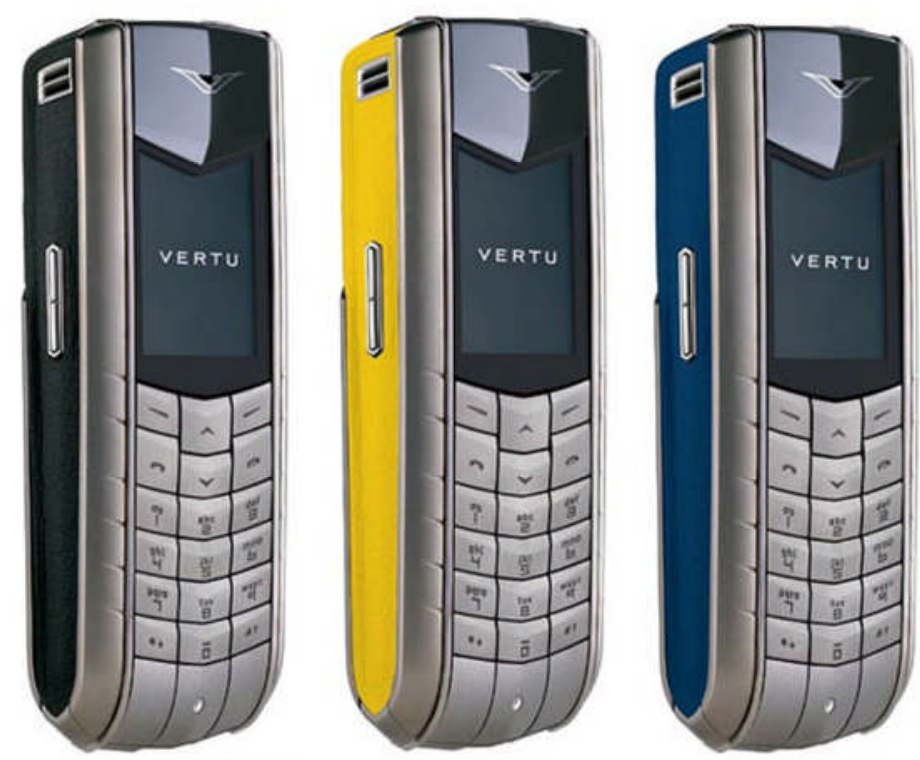

\section{Gambar 1. Merek Premium Telepon Seluler}

Citra, yang direpresentasikan oleh merek, seolah sudah menjadi konsumsi sehari-hari masyarakat modern. Bahkan, dalam banyak hal, nilai citra (image) yang melekat pada sebuah produk bahkan telah dianggap lebih penting daripada produknya (commodity) itu sendiri. Begitu penting dan dominannya citra, sampai Phillip Moris, perusahaan rokok terbesar di Amerika Serikat, pada awal 2005 silam berani mengakuisisi PT HM Sampoerna Tbk senilai lima kali lipat nilai aset yang tercatat dalam pembukuannya (Tempo, 27 Maret 2005: 107-115; Marketing, No. 05/V/Mei 2005: 14-15). Atau, merek Coca-Cola jika dijual jauh lebih mahal daripada nilai asetnya di seluruh dunia. Dominannya citra telah membuat perilaku konsumen berubah, mereka tidak lagi mengkonsumsi produk, melainkan mengkonsumsi citra. Inilah yang disebut sebagai komodifikasi, dimana komoditas dianggap sebagai representasi dari citra tertentu yang melekat secara inheren pada kediriannya, sekaligus menandakan bahwa citra telah dianggap sama nyatanya dengan benda (commodity). Bahkan, lebih jauh 
lagi, citra kemudian lebih penting daripada komoditas. Dalam bahasa pemasaran: mereka tidak lagi sekadar butuh pasta gigi, melainkan Pepsodent; tidak hanya menginginkan mobil, tetapi Jaguar; atau, tak cukup menggenggam ponsel, melainkan Vertu.

\section{RELASI PENCITRAAN-PRODUK DAN TEORI HARGA}

Teori harga, sebagaimana telah disebut di muka, merupakan titik temu (rallying point) antara teori perilaku konsumen (yang memunculkan permintaan, demand), dengan teori perilaku produsen (yang memunculkan penawaran, supply), dan teori produksi (yang memunculkan alokasi sumber daya). Dengan kata lain, harga merupakan hasil akhir dari bekerjanya mekanisme pasar, yang menghubungkan manusia ekonomi (baik yang berkedudukan sebagai produsen maupun konsumen) dengan komoditas (sumber daya). Jika kita mengingat kembali definisi ilmu ekonomi, maka tiap rumah tangga ekonomi dalam urusan untuk memenuhi kebutuhannya memang berurusan dengan relasi antara manusia dengan alam, yang dalam tinjauan klasik sering disebut man-land relation.

Jika teori harga merupakan titik temu antara perilaku konsumen, perilaku produsen, dan teori produksi, maka lebih dominannya efek pencitraan dalam menentukan preferensi konsumen, merupakan gejala bahwa perilaku konsumen lebih mendominasi proses penentuan harga daripada faktor lainnya. Artinya, harga yang terbentuk dalam proses pertukaran atau perdagangan bobot terbesarnya berasal dari preferensi konsumen.

Sekilas, hampir tidak ada persoalan dari pengaruh kuat citra dalam mengatur transaksi yang ada di pasar. Tapi benarkah demikian?

Dalam literatur ekonomi klasik, kita mengenal distingsi antara nilai guna (use value) dengan nilai tukar (exchange value). Nilai guna adalah nilai yang dimiliki oleh sebuah komoditas dalam hubungannya dengan kebutuhan yang ada pada manusia. Atau, Lury, dengan mengutip Marx, menyebut nilai guna sebagai "nilai yang dilekatkan pada barang-barang oleh kebutuhan manusia 'murni' yang berkaitan dengannya" (Lury, 1998: 97). Kita bisa mengambil contoh air dan nasi. Air memiliki nilai guna sebagai penghilang dahaga atau sumber kehidupan, dan nasi memiliki nilai guna sebagai pemenuh kebutuhan manusia akan karbohidrat. Sedangkan, nilai tukar adalah nilai yang dimiliki oleh sebuah komoditas dalam hubungannya dengan komoditas lain. Sebagai contoh, jika harga semangkuk bakso adalah Rp5.00o dan harga sebuah goreng pisang adalah Rp5oo, maka dikatakan bahwa nilai tukar bakso adalah sama dengan sepuluh (10) buah pisang goreng, atau nilai tukar pisang goreng adalah sepersepuluh (1/10) dari semangkuk bakso. 
Dari berbagai literatur ekonomi yang sudah ditulis, dan juga dari pengalaman sehari-hari yang kita alami, nilai guna yang besar tidak selalu kongruen dengan nilai tukar yang besar. Artinya, sebuah komoditas yang memiliki kegunaan sangat penting, nilai tukarnya belum tentu besar. Contohnya adalah air tadi. Meski air merupakan komoditas yang vital bagi kehidupan manusia, harga seliter air jauh lebih murah daripada harga seliter BBM (Bahan Bakar Minyak), yang dalam hubungannya dengan kebutuhan kehidupan manusia, nilai gunanya lebih kecil. Demikian juga sebaliknya, sebuah komoditas yang nilai gunanya kecil, bisa jadi nilai tukarnya justru sangat besar. Contoh yang sering dikemukakan oleh bukubuku daras ekonomi adalah berlian. Jika dilihat dari kegunaannya, berlian bahkan bisa dikatakan hampir tidak berguna bagi kebutuhan dasar manusia, tapi nilai tukarnya ternyata sangat besar.

Masalah tadi, yaitu kenapa sebuah komoditas yang nilai gunanya besar justru nilai tukarnya kecil, atau sebaliknya, yaitu kenapa sebuah komoditas yang nilai gunanya kecil ternyata nilai tukarnya sangat besar, adalah masalah yang tidak bisa dipecahkan oleh ilmu ekonomi klasik. Masalah ini sering disebut sebagai paradoks nilai (paradox of value), yang sering disebut sebagai telah membuat frustrasi para ekonom Klasik sejak Adam Smith hingga John Stuart Mill (Skousen, 2001: 169-72). Zimmerman (1955: 104) menyebut paradoks nilai ini dengan istilah antinomi nilai (waardeantinomie), sebuah masalah yang membuat ilmu ekonomi menghadapi kemacetan besar (major stumbling block).

\section{AKAR SUBYEKTIVITAS: TEORI UTILITAS}

Masalah paradoks nilai tidak bisa dipecahkan oleh para ekonom Klasik. Baru pada abad ke-18, muncul jalan keluar, yang sekaligus menandai kelahiran Ekonomi Neoklasik. Pemecahan yang diajukan itu disebut teori utilitas (theory of utility). Perilaku konsumen biasanya dijelaskan melalui prinsip bahwa orang cenderung memilih barang-barang atau jasa-jasa yang nilainya paling tinggi. Dan para pemikir Neoklasik mengajukan gagasan bahwa ukuran mengenai nilai barang adalah utilitas (utility). Secara harfiah utilitas berarti kepuasan, atau lebih tepatnya suatu konsep yang mengacu kepada kesenangan atau kegunaan subjektif yang dirasakan oleh seseorang dari mengkonsumsi sesuatu barang atau jasa (Samuelson dan Nordhaus, 1995: 101; bdk. Nicholson, 2002: 57).

Inti dari teori utilitas adalah bahwa harga komoditas tidak ditentukan oleh proses produksi atau jumlah tenaga kerja yang terlibat dalam pembuatan komoditas bersangkutan, melainkan ditentukan oleh preferensi konsumen atas komoditas tadi. Dengan kata lain, bagi para pemikir Neoklasik, nilai sebuah komoditas berasal dari penilaian subjektif pengguna individual. Untuk mudahnya, contoh berikut bisa dijadikan ilustrasi. 
Segelas air yang kita minum memberikan utilitas, atau kepuasan, yang cukup besar $\left(\mathrm{U}_{1}\right)$. Tapi karena segelas air saja $\left(\mathrm{Gl}_{1}\right)$ mungkin tidak akan cukup untuk menghilangkan dahaga, maka kita juga membutuhkan tambahan gelas air berikutnya. Tapi pada gelas kedua (G2) yang kita minum, nilai kepuasannya ( $\left.\mathrm{U}_{2}\right)$ mungkin telah berkurang dari gelas pertama tadi $\left(\mathrm{U}_{1}>\mathrm{U}_{2}\right)$. Jika kita mengkonsumsi lebih dari segelas air, nilai kepuasan dari masing-masing tambahan gelas air yang diminum akan semakin mengecil $(\mathrm{U} x<\mathrm{U} x-1)$, hingga pada akhirnya kita tidak lagi memperoleh manfaat dari tambahan air yang diminum. Gelas kesekian mungkin justru akan membuat kita muntah-muntah karena kekenyangan minum.

(a)

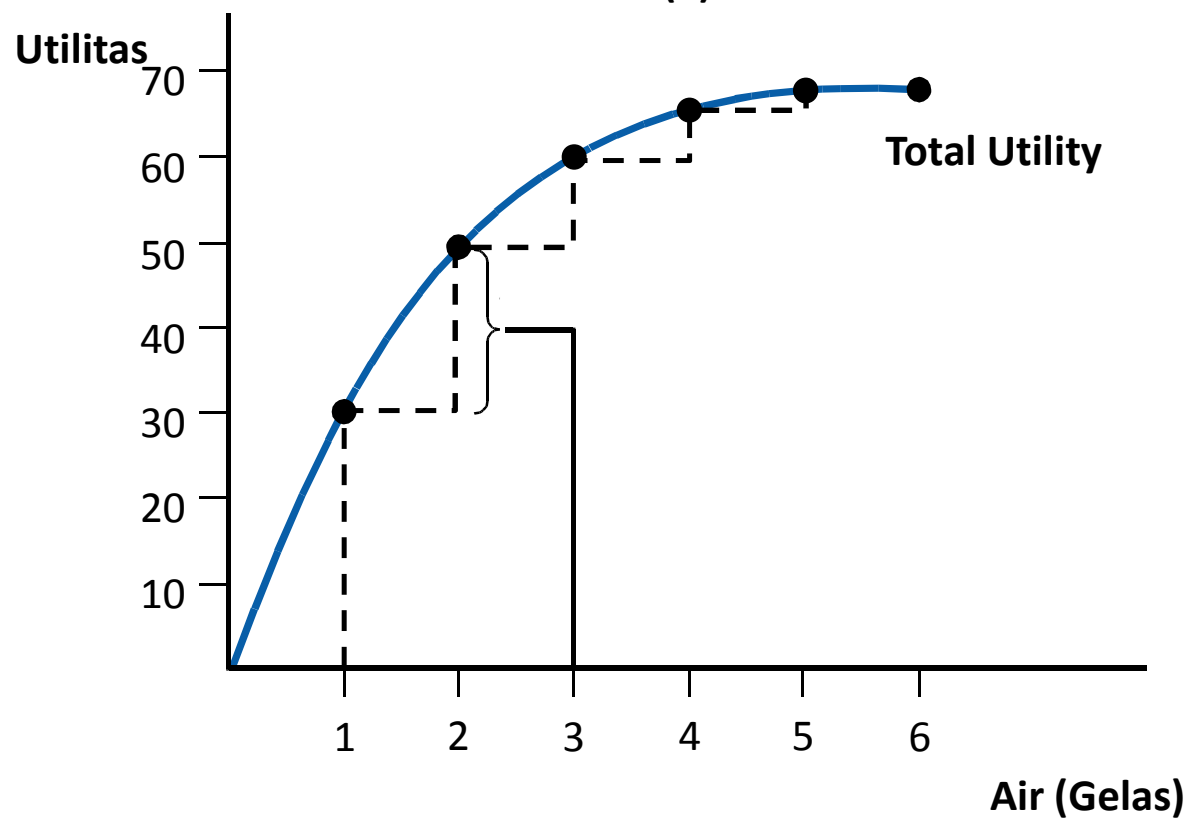

(b)

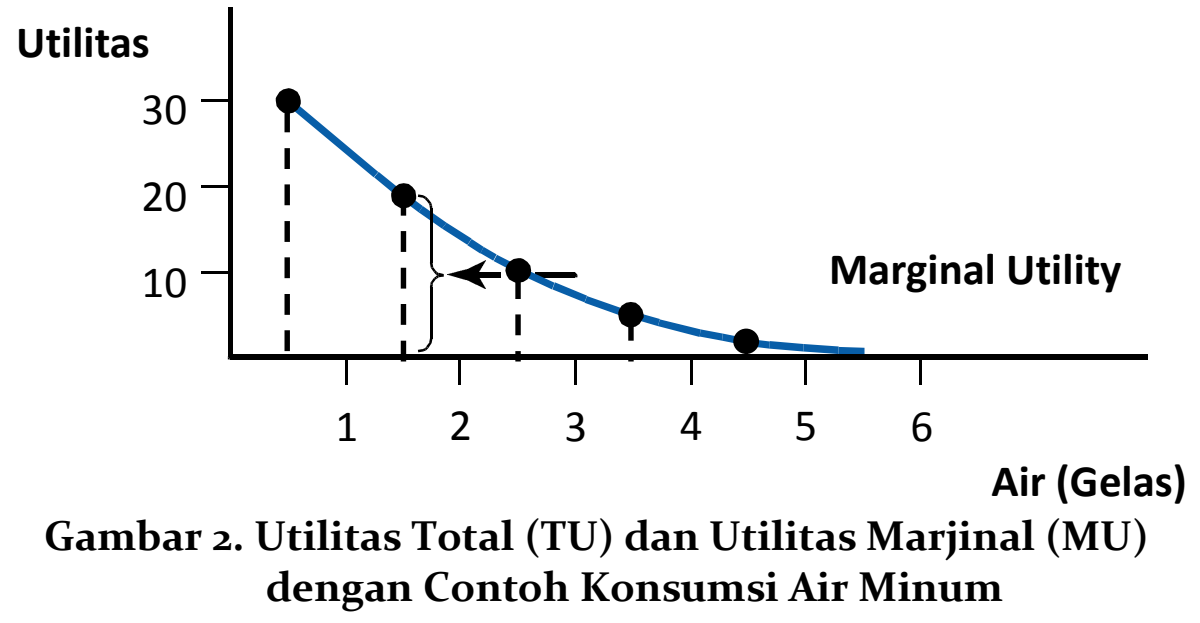


Besaran nilai dari masing-masing gelas air yang kita minum secara berurutan disebut sebagai utilitas marjinal (Marginal Utility, MU), sedangkan kepuasan total dari jumlah gelas air yang diminum disebut sebagai Utilitas Total (Total Utility, TU). Pada prinsipnya demikianlah cara kerja teori utilitas dalam menjelaskan nilai sebuah komoditas, meskipun pendekatan utilitas marjinal kemudian mendapat kritik dan digantikan oleh utilitas kardinal (Cardinal Utility). Kritik itu berangkat dari kenyataan bahwa kita tidak bisa memberikan bobot utilitas dari komoditas yang kita konsumsi. Berapa nilai utilitas segelas air yang kita minum? Berapa utilitas gelas berikutnya? Karena pertanyaan dan proses penilaian semacam ini tidak bisa dijawab, atau bahkan mustahil dijawab, maka yang bisa kita lakukan hanya membandingkan utilitas sebuah komoditas dengan utilitas komoditas lainnya. Inilah yang disebut sebagai utilitas kardinal.

Teori utilitas membawa implikasi serius. Dengan diterimanya teori ini sebagai penjelasan atas nilai komoditas, maka teori nilai-biaya produksi obyektif kemudian diabaikan oleh ilmu ekonomi Neoklasik. Artinya, harga sepatu tidak lagi ditentukan oleh seberapa besar ongkos produksi yang diperlukan untuk menghasilkan sepatu, melainkan oleh seberapa besar tingkat preferensi konsumen (yang diukur melalui utilitas, dan secara konkret melembaga melalui permintaan) atas sepatu bersangkutan. Inilah yang membuat kenapa teori ekonomi Neoklasik disebut juga sebagai teori ekonomi subjektif (economic subjectivism). Satu-satunya faktor obyektif yang diperhitungkan oleh teori utilitas adalah jumlah persediaan komoditas. Ini juga yang menjelaskan kenapa harga air menjadi murah, meskipun nilai gunanya (use value) besar. Itu dikarenakan jumlah persediaan air melimpah, sehingga semakin kecil keinginan orang terhadap unit terakhir komoditas tersebut. Ketersediaan kuantitas yang sedemikian besar telah sangat merendahkan utilitas marjinalnya (Samuelson dan Nordhaus, 1995: 112).

Secara ringkas kita bisa merumuskan bahwa preferensi konsumen, yang hadir dalam bentuk permintaan ( $\mathrm{D}$, demand), pada akhirnya menentukan harga akhir komoditas (P, price), dimana pada gilirannya akan menentukan arah aktivitas produksi. Jadi, harga komoditas dibentuk bukan oleh harga faktor produksi (upah, sewa, dan profit), melainkan oleh preferensi/permintaan konsumen. Permintaan akhir itulah yang kemudian menciptakan harga dari faktor-faktor produksi. Rantai pembentukan harga semacam ini disebut sebagai price-driven-costing (Kotler, 2000: 352). Rantai ini berbeda dengan penjelasan yang dikemukakan oleh teori ekonomi Klasik, terutama sebagaimana yang banyak dieksplorasi oleh Marx, bahwa harga komoditas ditentukan oleh ongkos faktor produksi, atau yang biasa disebut cost-driven-pricing. 


\section{KONSUMSI ROKOK DAN INKOHERENSI SUBYEKTIVITAS}

Kenapa para perokok terus merokok, padahal mereka tahu bahayanya merokok?

Pertanyaan tersebut merupakan titik berangkat yang baik untuk menggali pemahaman bahwa perilaku konsumen secara umum seringkali tidak bisa dijelaskan oleh penjelasan-penjelasan yang bersifat obyektifrasional. Risiko kesehatan, sebagaimana yang tertera di tiap kemasan rokok, dan menurut tinjauan medis itu bersifat obyektif, nyatanya tidak banyak mengubah perilaku orang berkaitan dengan kebiasaan merokok. Oleh karena itu diperlukan sebuah penjelasan lain, di luar yang bersifat obyektif dan rasional, untuk menerangkan bagaimana perilaku merokok bisa bertahan.

\section{BAHAYA ROKOK}

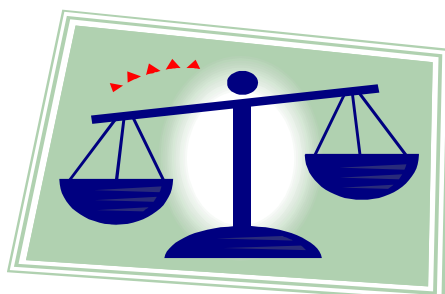

\begin{tabular}{l} 
Angka kematian akibat rokok adalah 5,4 juta/tahun. Artinya \\
tiap menit ada satu orang yang meninggal karena rokok. \\
Sekitar 100 juta orang di dunia terbunuh oleh tembakau pada \\
abad ke-20. \\
\hline Para perokok dapat kehilangan 20-25 tahun masa hidupnya \\
karena rokok. \\
Rokok adalah penyebab utama berbagai penyakit \\
kardiovaskuler (saluran pernapasan), penyakit penyebab \\
kematian nomor delapan di Amerika Serikat. \\
Rokok merupakan penyebab 25 jenis penyakit kronis di tubuh \\
manusia. Separuh dari para perokok meninggal karena \\
berbagai penyakit tadi. \\
Rokok merupakan salah satu penyebab kemiskinan di negara \\
berkembang. \\
\hline Sumber: Disarikan penulis dari berbagai sumber. \\
\hline
\end{tabular}

\section{Gambar 3. Risiko yang Disebabkan oleh Rokok}

Dari berbagai penelitian yang telah dilakukan, seperti oleh Komalasari dan Helmi (tanpa tahun), serta BALAIRUNG (2003, 2004), misalnya, sebab- 
sebab yang mendorong orang untuk merokok lebih bersifat psikologis daripada rasional. Atau, dengan kata lain, perilaku merokok sebenarnya lebih banyak didorong oleh pertimbangan yang bersifat subyektifemosional, daripada obyektif-rasional. Untuk keperluan pemaparan di bagian yang akan datang, pertimbangan yang bersifat subyektif-emosional sebagaimana yang melekat pada perilaku merokok dapat kita sebut sebagai gejala subjektivisme, atau gejala psikologisme. Penggunaan istilah subjektivisme ini sealur dengan tujuan awal penulisan artikel ini, yaitu untuk membuktikan adanya subyektivitas dalam teori harga sebagaimana diajarkan oleh ilmu ekonomi Neoklasik, yang sering disebut sebagai ilmu ekonomi subjektivisme (economic subjectivism).

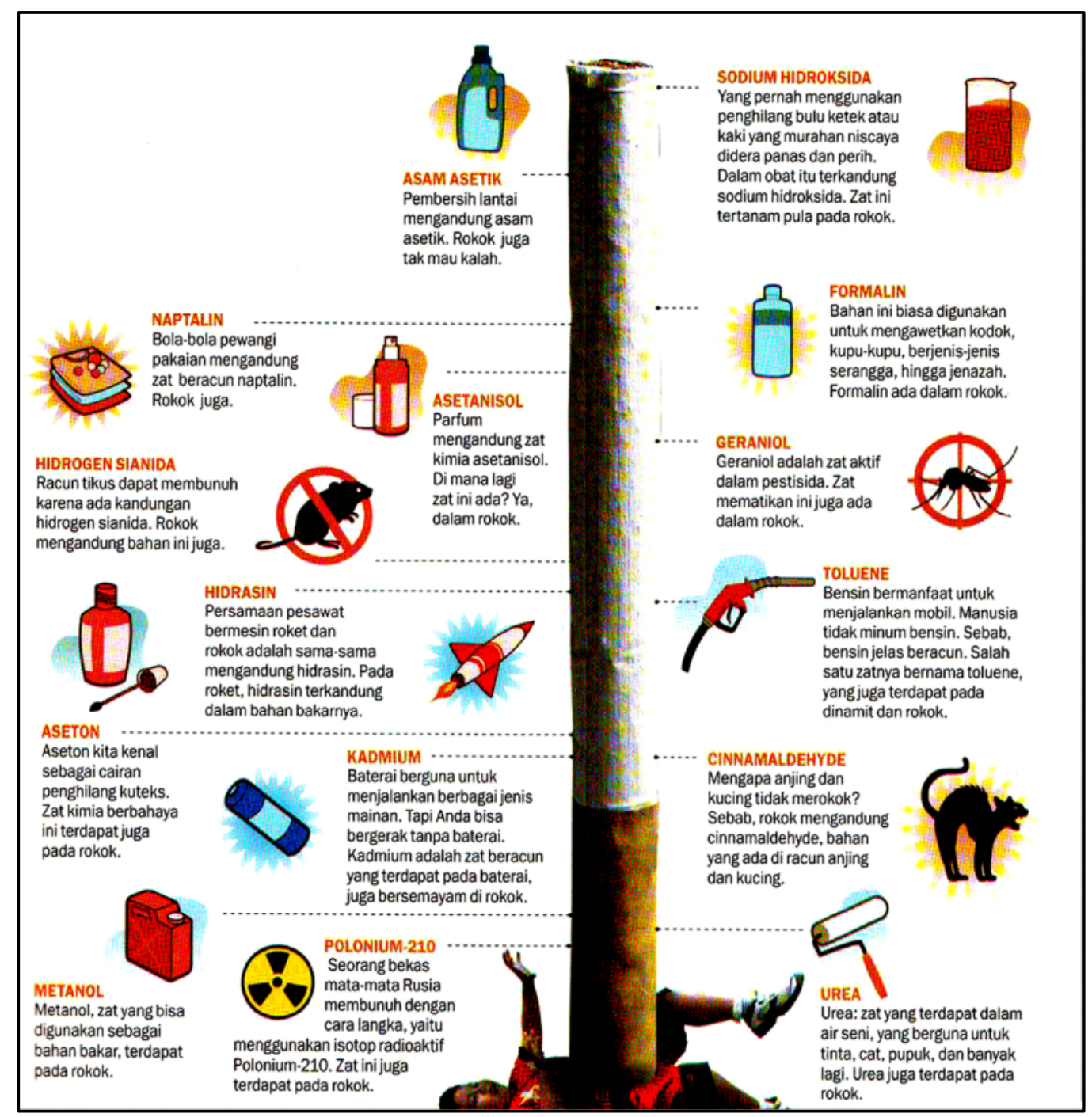

Gambar 4. Kandungan Rokok dan Bahayanya 
Tidak sulit untuk menghubungkan bahwa gejala subjektivisme dalam perilaku konsumsi rokok merupakan salah satu contoh bagaimana teori utilitas bekerja dalam kehidupan nyata. Hanya saja, berbeda dengan teori ekonomi Neoklasik yang mendudukan subjektivisme hanya sebagai penjelas kenapa sebuah komoditas dianggap bernilai, maka artikel ini mencoba melihat dari sisi sebaliknya, yaitu bahwa subjektivisme merupakan masalah yang telah menyebabkan beberapa komoditas terdevaluasi nilainya, atau menjadi masalah karena membuat delta harga antarkomoditas menjadi senjang dalam satuan yang signifikan. Melalui problematisasi itu kita akan melihat bahwa ukuran-ukuran utilitas yang bersifat subjektif bukanlah merupakan ukuran yang cukup (sufficient) untuk menentukan nilai tukar antarberbagai komoditas yang hendak dipertukarkan di pasar, karena memberi peluang bagi terjadinya penilaian berlebih ataupun kekurangan dalam selisih yang cukup besar. Dengan kata lain, prinsip-prinsip utilitas yang bersifat subjektif memberi peluang bagi kemungkinan sebuah komoditas dinilai terlalu tinggi (over-compensated) dari "ukuran semestinya", sementara komoditas lain dinilai terlalu rendah (undercompensated). Ukuran semestinya di sini sengaja diberi tanda kutip karena ini merupakan medan perdebatan yang tidak sederhana. Ukuran itu bukan hanya menyangkut persoalan teknis dan teoritis, melainkan juga historis dan filosofis.

Selama kurang lebih tiga ratus tahun, sejak Bentham (1748-1832) mempublikasikan An Introduction to the Principles of Morals and Legislation pada 1781, yang mengintroduksi filsafat utilitarian ke dalam ilmu-ilmu sosial, dan lalu gagasan itu dikonstitusikan oleh para pemikir Neoklasik ke dalam ilmu ekonomi pada abad ke-19, orang sudah lupa bahwa teori ekonomi yang mereka pelajari hari ini sebenarnya dibangun oleh gagasan filsafat tertentu. Tanpa mengusik gagasan-gagasan dasar itu, setiap upaya pemecahan masalah ekonomi, seperti misalnya kemiskinan petani dan rendahnya nilai tukar sebagaimana yang sedang kita bicarakan, kita tidak akan pernah mencapai hal-hal penting kecuali sekadar seperti menambal kain yang sudah compang-camping. Secara umum pembahasan ini berusaha untuk menjangkau hal-hal yang jarang disentuh itu, yaitu mencari koherensi antara persoalan-persoalan mikro, sebagaimana yang diwakili oleh perilaku konsumen yang subjektif, dengan persoalan-persoalan makro, sebagaimana yang diwakili oleh konsep seperti kemiskinan, misalnya. Tentu saja ada banyak keterbatasan yang dihadapi untuk itu dan pembahasan ini sudah membatasi eksplanasinya hanya sejauh apa yang sudah ditetapkan pada bagian pendahuluan.

Sejauh yang dapat ditelusuri, penelitian-penelitian mengenai perilaku konsumen selama ini bisa diklasifikasi sebagai terbagi ke dalam dua ruang lingkup, yaitu (1) yang bersifat praktis, serta (2) yang bersifat diskursif. 
Ruang lingkup yang bersifat praktis umumnya didominasi oleh studi pemasaran dan manajemen, baik itu yang bersifat akademik sebagaimana yang dilakukan di lingkungan perguruan tinggi, maupun yang bersifat terapan di perusahaan. Sedangkan ruang lingkup yang bersifat diskursif, secara umum berada dalam apa yang disebut sebagai kajian cultural studies. Dari pembagian sederhana ini nampak bahwa penelitian mengenai perilaku konsumen terbelah ke dalam kepentingan yang saling bertentangan dan tidak koheren satu sama lain. Manajemen dan pemasaran umumnya menggunakan studi perilaku konsumen untuk apa yang bisa kita sebut sebagai "kepentingan pasar". Keduanya mempelajarai perilaku konsumen bukan untuk kepentingan konsumen, baik secara individual maupun kolektif, melainkan untuk kepentingan produsen dan pemilik modal. Sebaliknya, cultural studies, melalui berbagai pendekatan kritis yang dimilikinya, justru berusaha untuk membebaskan konsumen dari jerat kepentingan pasar.

Dalam kaitannya dengan studi perilaku konsumen, harus diakui bahwa ilmu ekonomi tertinggal jauh dari bidang-bidang yang telah disebutkan tadi, kecuali barangkali tidak termasuk dengan pemikiran-pemikiran Thorstein Veblen (1857-1929). Karya-karya Veblen, seorang ekonom Amerika yang namanya kemudian dinisbatkan sebagai pendiri aliran Ekonomi Kelembagaan (Institutional Economics), menjadi perkecualian karena Veblen sejak awal sudah mempersoalkan asumsi-asumsi yang dibangun oleh teori ekonomi Neoklasik berkaitan dengan soal perilaku aktor ekonomi. Dia, misalnya, memperkenalkan istilah conspicuous consumption, sebuah istilah yang digunakan untuk merujuk gejala baru di akhir abad ke-19 dalam kegiatan konsumsi, dimana orang justru memiliki preferensi terhadap komoditas berharga mahal. Semakin mahal harga komoditas, maka konsumen akan semakin menggilainya (Veblen, 1957 [1899]).

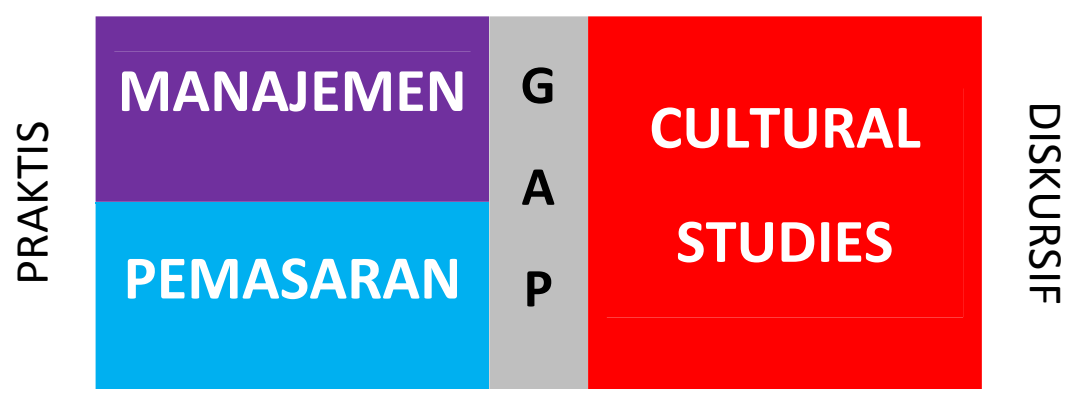

Gambar 5. Klasifikasi Studi Perilaku Konsumen

Kembali lagi ke soal ketertinggalan ilmu ekonomi, karena ia tertinggal dalam menjelaskan perilaku konsumsi, ilmu ekonomi menjadi kehilangan arah dalam menjelaskan implikasi perubahan perilaku tadi terhadap 
struktur perekonomian secara umum. Bisa dikatakan bahwa perilaku konsumsi telah berlari jauh meninggalkan kerangka pemahaman usang, seperti misalnya andaian-andaian bahwa keputusan konsumen didasarkan atas pertimbangan rasional, sementara ilmu ekonomi masih meyakini sebaliknya: setiap orang yang ada di pasar adalah rasional dan mereka menguasai informasi yang sama dengan pelaku pasar lainnya.

Padahal, jika kita membaca literatur dengan seksama, asumsi-asumsi ini sebenarnya telah banyak dibantah oleh beberapa ekonom. Dalam disertasinya di MIT, Kenneth J. Arrow, secara matematis berhasil membuktikan bahwa pilihan sosial (public choice) yang dibuat oleh individu tidaklah bersifat rasional. Dalam konteks sosial, individu bisa melakukan tindakan yang berbeda dari keyakinan atau keinginan pribadinya. Sehingga asumsi transitivitas, yang menyatakan bahwa keputusan akhir dalam tindakan seseorang merupakan konklusi logis atas berbagai pertimbangan yang dimiliki sebelumnya, sebagaimana yang diyakini oleh teori ekonomi konvensional, dalam pembuktian Arrow ditolak. Artinya, transitivitas hanya ada dalam asumsi, tapi tidak demikian dalam kenyataan (Arrow, 1973 [1951], Sixth Printing). Gagasan itu kemudian mengantarkan Arrow mendapat hadiah Nobel Ekonomi pada 1972. Pembahasan mengenai pemikiran Arrow dan implikasinya dalam kerangka yang lebih luas bisa dilihat pada karya Norman Frohlich dan Joe A. Oppenheimer (1984), dan Allan M. Feldman (2000).

Pembahasan mengenai perilaku konsumen dan kegiatan konsumsi ini membuka sebuah permasalahan yang bersifat mendasar: di satu sisi ilmu ekonomi (Neoklasik) membela keyakinan bahwa nilai sebuah komoditas ditentukan oleh subjektivitas konsumen, tapi di sisi lain ia menjelaskan bahwa perilaku konsumen adalah rasional. Bagaimana bisa tindakan konsumen bersifat subjektif dan rasional sekaligus? Dalam kerangka seperti apa dua hal yang berbeda secara konseptual itu bisa menyatu? Meski tidak beroposisi biner, istilah subjektivitas dan rasionalitas memang memiliki andaian yang berbeda, bahkan cenderung bersifat kontradiktif satu sama lain. Subjektivitas lebih bernilai emotif, sedangkan rasionalitas lebih bernilai objektif. Dari soal perilaku konsumen ini, kita menemukan bahwa ilmu ekonomi Neoklasik belum bisa membedakan perbedaan dimensional antara kerangka subjektif dengan objektif, serta dalam keadaan bagaimana keduanya berinteraksi.

Perlu disadari bahwa dimensi analisis permintaan dan penawaran dengan dimensi analisis perilaku konsumen memang berbeda. Secara teknis, analisis permintaan dan penawaran menyandarkan penjelasannya pada relasi antara kuantitas barang dengan harga, sehingga karena ia berbicara mengenai satuan-satuan yang terukur, maka secara sederhana kita bisa menyebutnya sebagai berdimensi obyektif. Sementara itu, perilaku konsumen yang membentuk permintaan dan penawaran, bekerja menurut 
aturan dalam dimensi yang berbeda, yaitu sujektivisme, dengan satuansatuan yang sulit diukur. Dan ilmu ekonomi masih belum berhasil menjembatani dua dimensi yang berbeda ini (bdk. Gunawan, Patunru, dan Winoto, 1997: 11-40; Azis, 1996). Bahkan, bisa dikatakan, ilmu ekonomi belum lagi menyadari mengenai adanya perbedaan dimensi antara penjelasan agregat (baca: makro) dan mikro ini di level cara kerja.

Indikasi kalau ilmu ekonomi tidak dan/atau belum menyadari perbedaan dimensional tadi terlihat pada keterangannya ketika menjelaskan proses pertukaran, dimana penjelasan ekonomi masih berkutat di soal agregat penawaran (supply) dan permintaan (demand). Dengan berhenti hanya sampai di perbincangan mengenai permintaan dan penawaran, penjelasan ekonomi mengandaikan bahwa agregat makro disusun berdasarkan kerangka akumulasi faktor mikro. Ilmu ekonomi gagal memahami bahwa penjelasan agregat memiliki logika yang berbeda dengan penjelasan mikro, sebagaimana yang dianalogkan oleh penelitian Arrow (lihat catatan kaki sebelumnya).

Para sosiolog dan fisikawan sebenarnya lebih maju dari para ekonom dalam menyadari perbedaan dimensional ini. Anthony Giddens, sosiolog di LSE (London School of Economics), melalui Teori Strukturasi yang dibangunnya berusaha menjelaskan titik temu antara bagian (the parts) dengan keseluruhan (the whole), yang dalam ilmu ekonomi analog dengan perbedaan dimensional antara ekonomi mikro dengan makro. Selama ini, menurut Giddens, ilmu sosial dan humaniora baru menjelaskan apa dan bagaimana perilaku bagian (Agen, dalam istilah Giddens) dan perilaku keseluruhan (Struktur, dalam istilah Giddens) seolah keduanya merupakan kerangka tersendiri yang saling terpisah, dan mengabaikan kemungkinan bahwa obyek kajian ilmu sosial dan humaniora yang seharusnya adalah persis berada pada titik temu antara keduanya, yaitu menjelaskan dalam aturan yang bagaimana Agen dan Struktur terlibat dalam sebuah tindakan sosial (Priyono, 2000; 2003). Dalam fisika, gagasan serupa bahkan sudah lebih lama disusun. Fritjof Capra, fisikawan teoritis yang mengajar di banyak universitas terkemuka dunia, seperti Universitas Vienna, Paris, Stanford, dan California, telah lama membawa persoalan distingsi antara the parts dan the whole ini sebagai masalah keilmuan secara generik. Artinya, ini bukan hanya masalah ilmu ekonomi atau ilmu sosial semata, melainkan masalah ilmu pengetahuan sosial dan alam sekaligus.

Dalam buku Belonging to the Universe (1991), Capra meringkaskan masalah-masalah mendasar yang dihadapi ilmu pengetahuan. Paradigma lama ilmu pengetahuan meyakini bahwa dalam setiap sistem yang kompleks, dinamika dari keseluruhannya (the whole) hanya dapat dipahami melalui sifat bagian-bagiannya (the parts). Ini yang membawa fisika dan fisikawan lebih suka menyelidiki zarah-zarah yang renik untuk menyingkap rahasia alam semesta. Tapi Capra mengajukan gagasan lain, yaitu bahwa 
kita membutuhkan sebuah paradigma baru dimana hubungan antara bagian dan keseluruhan bersifat terbalik. Dalam paradigma baru, sifat-sifat bagian dapat dimengerti hanya melalui dinamika keseluruhannya (Capra, 1999: xvi). Di Indonesia, pemikir yang segenerasi dengan Capra dan juga mengajukan gagasan sejenis, tapi malah dengan elaborasi yang lebih mendasar dilakukan oleh Hidajat Nataatmadja. Doktor ekonomi pertanian yang juga adalah fisikawan teoritis itu sejak awal 1970-an telah memperkenalkan dilema bagian dan keseluruhan, yang disebutnya sebagai eigen system (sistem kedirian) dan sistem referensi (the whole), dengan pendekatan yang otentik (bdk. Nataatmadja, 1989; 1991; 1992; 2006). Sayangnya, gagasan Hidajat tidak banyak dipahami oleh para ilmuwan di tanah air.

Kembali ke soal klasifikasi atas studi konsumen di atas, jika dihubungkan dengan teori yang dikemukakan Arrow, Giddens, Nataatmadja, dan Capra, perihal perbedaan dimensional antara individual value dan social choice, bagian dan keseluruhan, agen dan struktur, sistem kedirian dan sistem referensi, maka baik ruang lingkup praktis (Manajemen dan Pemasaran) maupun diskursif (Cultural Studies) yang telah disebutkan, pada dasarnya kedua ruang tadi berada di level mikro, yang hanya memberikan penjelasan atas perilaku agen, individual value (sebuah konsep yang analog dengan preferensi individu), dan masih belum berbicara mengenai struktur atau keseluruhan, serta interaksi antara keduanya. Sebagaimana yang sudah dibuktikan Arrow, social choice bukanlah konklusi logis dari individual value, sehingga perilaku struktur, atau sebuah gejala agregat, tidak bisa dijelaskan dengan mengakumulasikan perilaku agen atau preferensi individual.

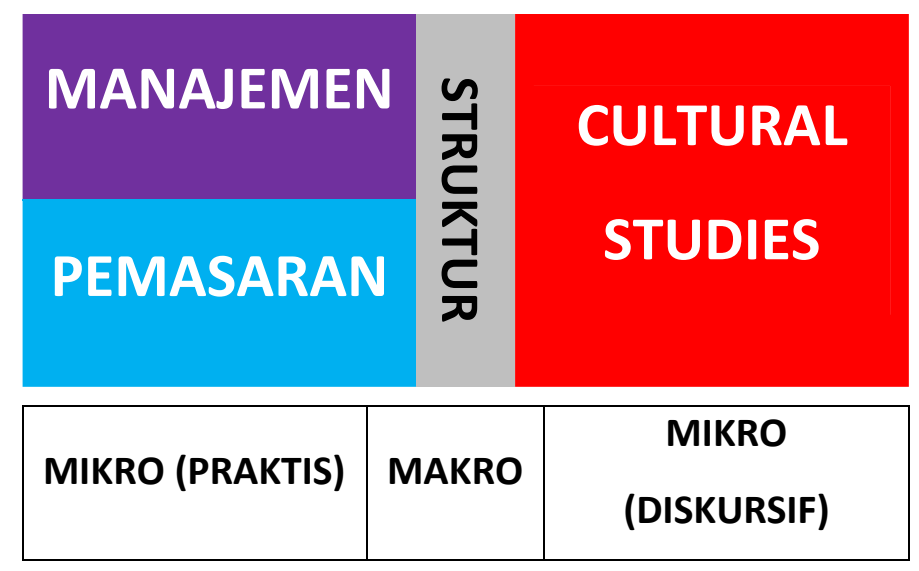

\section{Gambar 6. Taksonomi Studi Perilaku Konsumen}

Jika perilaku Agen 1 adalah P1, dan perilaku Agen 2 adalah P2, dan demikian seterusnya, dan Agen 1, Agen 2, hingga Agen (n) membentuk 
sebuah masyarakat $S$, maka bagaimana perilaku $S$ tidak akan sama dengan penjumlahan $\mathrm{P} 1$ hingga $\mathrm{P}(\mathrm{n})$. Inilah yang dalam ilmu sosial disebut bahwa masyarakat, atau pilihan sosial, atau struktur, tidaklah lama dengan individu massal atau penjumlahan seluruh perilaku individu yang menyusunnya $\left(\mathrm{P}_{1}+\mathrm{P}_{2}+\mathrm{P}_{3} \ldots+\mathrm{Pn}\right)$. Ini menunjukkan kalau masyarakat dan individu bekerja menurut logika yang berbeda. Jika diformulasikan secara matematis, maka kurang lebih gambarannya adalah sebagai berikut:

$$
\begin{array}{ll}
\mathrm{Ax} & =\mathrm{Px},(\mathrm{x}=1,2,3, \ldots \mathrm{n}) \\
\mathrm{S} & =\mathrm{A}_{1}+\mathrm{A}_{2}+\mathrm{A}_{3} \ldots+\mathrm{An} \\
\mathrm{PS} & \neq \mathrm{P}_{1}+\mathrm{P}_{2}+\mathrm{P}_{3} \ldots+\mathrm{Pn}
\end{array}
$$

\section{Keterangan}

Ax : Agen $x$

Px : Perilaku Agen $x$

$S$ : Masyarakat

PS : Perilaku Masyarakat

\section{MEMBONGKAR SUBYEKTIVITAS DENGAN SEMIOTIKA}

The aim of semiological research is to reconstitute the functioning of the system of signification other than language in accordance with the process typical of any structuralist activity, which is to build a simulacrum of the objects under observation.

-Roland Barthes (1964)

Sebenarnya, untuk membuktikan bahwa teori perilaku konsumen bersifat subyektif, kita bisa meminjam analisis semiotika yang biasanya digunakan dalam kajian linguistik atau studi komunikasi. Semiotika biasanya didefinisikan sebagai kajian atas tanda-tanda atau kode-kode (the study of signs). Ia melakukan studi atas sistem apapun yang memungkinkan kita menganalogikan entitas penyusunnya sebagai tanda-tanda atau sesuatu yang bermakna tertentu (Scholes dalam Budiman, 2003: 3). Atau, jika mengutip Barthes, tujuan sebuah penelitian semiotik adalah untuk merekonstitusi berfungsinya sistem signifikasi (penandaan) selain bahasa, dimana tugas ini dijalankan melalui langkah-langkah seperti yang dilakukan oleh seorang strukturalis, yaitu membangun sebuah simulakrum dari objek yang sedang diteliti. 
Pada mulanya, analisis ini memang berasal dari kajian linguistik atau studi bahasa, yang pertama kali diperkenalkan oleh Ferdinand de Saussure (1857-1913), seorang linguis berkebangsaan Perancis (bdk. Saussure, 1996 [1916]; Kridalaksana, 2005). Namun, dalam perjalanannya, kajian ini kemudian dipergunakan dan menjadi besar justru bukan di wilayah kajian bahasa, melainkan karena penggunaannya di bidang non-bahasa, terutama studi komunikasi. Secara umum, posisi semiotika tidak ubahnya seperti matematika dalam posisinya mengkodifikasi peristiwa atau sesuatu ke dalam angka dan persamaan. Semiotika adalah modus logika dalam bentuk kodifikasi kualitatif. Bahkan Charles Sanders Peirce menyebut semiotika adalah sinonim dari logika itu sendiri (Budiman, 2003: 3; 2005:34).

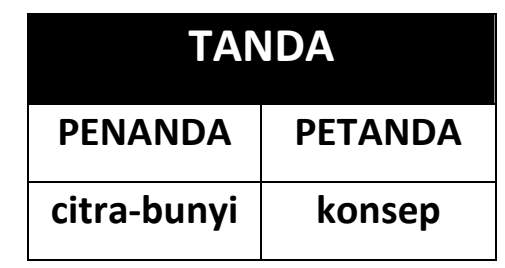

\section{Gambar 7. Elemen Tanda}

Tanda-tanda sendiri, menurut Berger (200o), "adalah sesuatu yang berdiri sendiri pada sesuatu yang lain atau menambahkan dimensi yang berbeda pada sesuatu, dengan memakai segala apapun yang dapat dipakai untuk mengartikan sesuatu hal lainnya". Ciri sebuah tanda (sign) adalah dia terdiri atas dua komponen, yaitu penanda (signifier) dan petanda (signified), yang mewakili aspek material dan aspek mental. Apa yang dimaksud dengan aspek material adalah seperti suara, huruf, bentuk, gambar, dan gerak; sedangkan aspek mental adalah konsep yang dirujuk oleh aspek material tadi, atau apa yang bisa kita sebut sebagai pengertian/makna. Saussure berpendapat bahwa tanda-tanda itu seperti lembaran kertas, dimana satu sisi kertas merupakan penanda (signifier), dan sisi lain kertas adalah petanda (signified), dan kertas itu sendiri adalah tanda (sign). Kita tidak bisa memisahkan penanda dan petanda dari tanda itu sendiri (Berger, 2000: 12).

Untuk lebih mudah memahami mengenai apa yang dimaksud, contoh berikut mungkin bisa membantu. "Supermarket", misalnya. Supermarket bisa menjadi tanda karena dia memiliki signifier (yaitu kata "supermarket" itu sendiri) dan signified (yaitu sebuah tempat nyata dimana orang bisa berbelanja berbagai macam kebutuhan dengan manajemen mutakhir). Kesatuan antara kata dengan kenyataan itulah yang membuat supermarket menjadi tanda (Sunardi, 2004: 42). Bagi orang yang butahuruf, atau yang belum sama sekali mengenal istilah itu, "supermarket" bukanlah tanda. Hubungan antara penanda (signifier) dengan petanda (signified) ini disebut sebagai hubungan simbolik, dalam arti signifier menyimbolkan signified. 
SUPERMARKET

Penanda (Signifier),

Aspek Material,

Berupa Huruf:

$S, U, P, E, R, M, A, R, K, E, T$
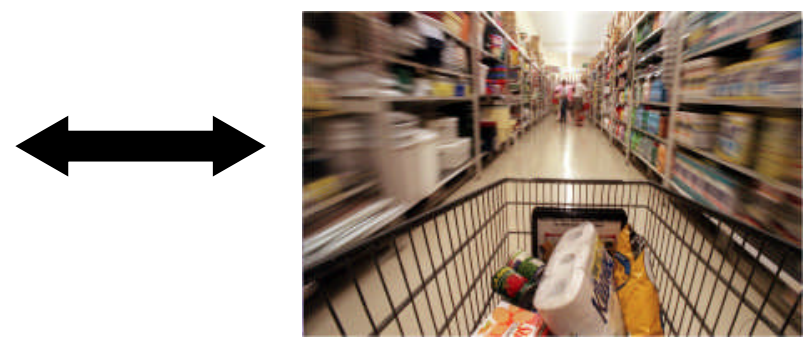

Petanda (Signified), Berupa tempat berbelanja

\section{Gambar 8. "Supermarket" sebagai Tanda}

Kata pengantar yang ditulis Seno Gumira Ajidarma bagi terjemahan buku Celia Lury, Consumer Culture (1996), bisa dijadikan contoh yang lebih konteks mengenai proses pemaknaan atas tanda dalam kegiatan konsumsi. Pada 1983, Seno berada satu rombongan dengan beberapa orang anggota suku Dayak Kenyah, yang menghuni pedalaman Mahakam, Kalimantan Timur, dalam sebuah perjalanan sebagai anggota tim Teater Sardono W. Kusumo yang diundang ke Hongkong untuk Festival Kesenian Asia. Petikan pengantar Seno berikut menggambarkan bagaimana proses penandaan (signifikasi) atas sebuah komoditas yang sama bisa saja berbeda.

Di sanalah (Hongkong-Pen.), di antara jalan-jalan layang yang berseliweran, teman-teman suku Dayak Kenyah-dengan kostum, tato dan telinga panjang yang khas-melahap hamburger kelas Big Mac dari McDonald's. Waktu itu, kata McDonald's sudah mempunyai makna khusus, meskipun belum menjadi McWorld seperti sekarang. Kata McDonald's sudah mendapat nuansa representasi cita-rasa internasional. Saya melahap sarapan Big Mac itu dengan kesadaran untuk menggauli suatu identitas budaya yang bukan dari dunia saya. Namun tidak begitu dengan teman-teman Dayak Kenyah itu. Bagi mereka Big Mac itu hanyalah roti dan daging-yang toh karena belum ketemu nasi tidak dianggap mengenyangkan. Padahal, kami sama-sama orang Indonesia (Ajidarma dalam Lury, 1998: x). 


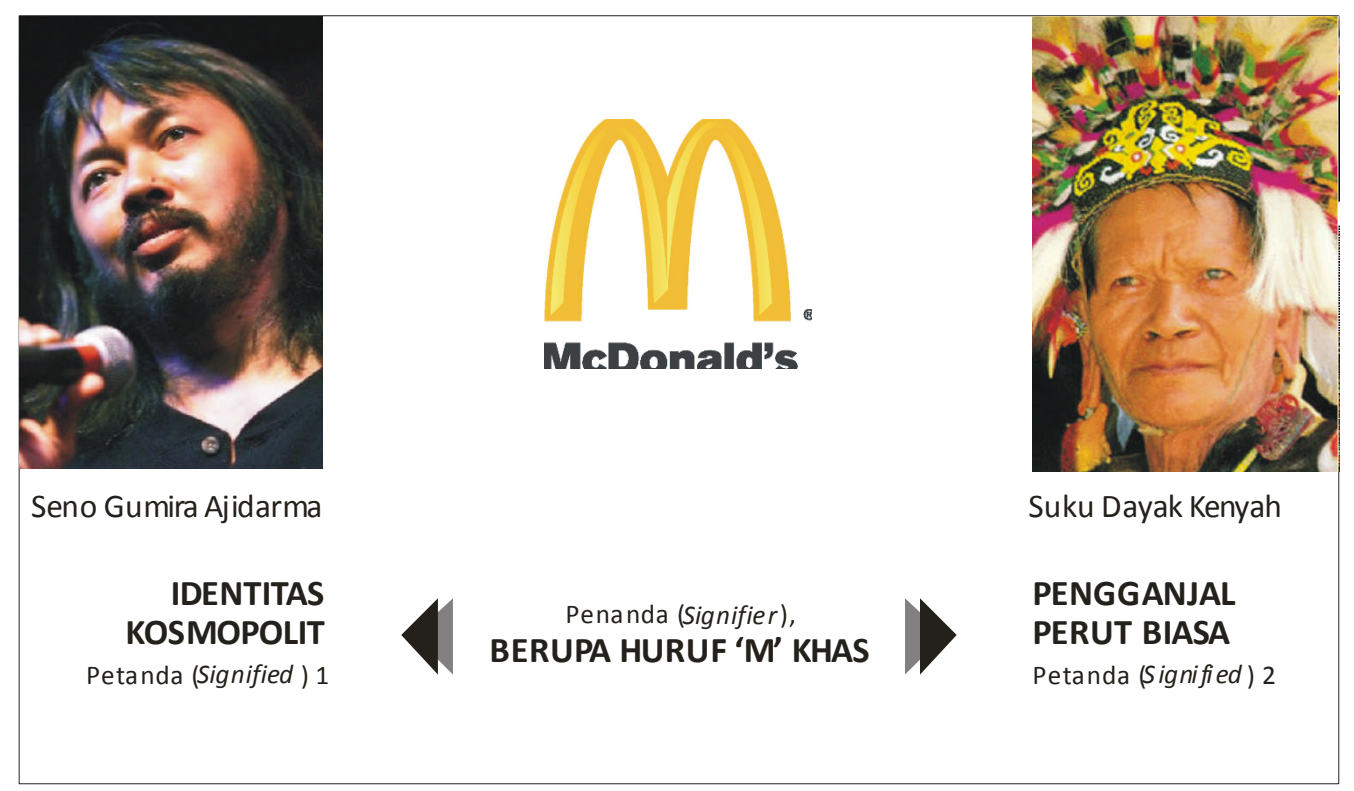

Gambar 9. McDonald's dan Dua Bentuk Penandaan

Baik Seno maupun suku Dayak Kenyah, sebagaimana tulisan Seno di atas, mereka sama-sama makan McDonald's, dalam sebuah kesempatan yang sama, di tempat yang sama, dan kebetulan mereka juga sama-sama orang Indonesia. Tapi bagi Seno, yang tinggal di Jakarta, sebuah kota kosmopolit yang terhubung secara 24 jam dengan dunia luar, dan dengan tradisi literasi yang berbeda dengan suku Dayak Kenyah yang tinggal di pedalaman Kalimantan, sepotong McDonald's tidak lagi sama dengan hanya sepotong daging dalam roti. McDonald's sudah menjadi simbol bagi sebuah identitas kosmopolit. Sedangkan, bagi suku Dayak Kenyah yang serombongan dengan Seno, McDonald's tidaklah menjadi tanda sebagaimana yang dibayangkan Seno, melainkan hanya sekerat daging yang tak ada bedanya dengan makanan yang biasa mereka santap di hutan. Bagi mereka, McDonald's tidak mewakili simbol apapun, kecuali sebagai pengganjal perut.

Jika dihubungkan dengan teori semiotik, penanda (signifier) yang sama, yaitu McDonald's, bisa memiliki petanda (signified) atau pemaknaan yang berbeda, yaitu: (1) sebagai identitas kosmopolit, sebagaimana yang dibayangkan Seno; dan (2) sekadar makanan pengganjal perut, sebagaimana yang dipersepsikan oleh suku Dayak Kenyah. Pada bentuk penandaan yang pertama, yaitu pada Seno, itu adalah contoh bekerjanya proses pencitraan, dimana kegiatan konsumsi tidak lagi ada kaitannya dengan apa yang secara umum dipahami sebagai "realitas". Melalui sudut pandang ini, sepotong Big Mac yang dijual oleh McDonald tak lagi sekadar merupakan makanan, melainkan juga sebuah tanda yang dikonstruksikan memiliki sejumlah makna, seperti identitas bagi orang sibuk, serta identitas yang mewakili sebuah kemajuan dan kosmopolitanisme (bdk. Ritzer, 2004: 139). 
Contoh tentang McDonald's ini sekaligus memberi kita sebuah catatan penting bahwa hubungan antara penanda dengan petanda bersifat arbitrer (semena), baik secara kebetulan maupun ditetapkan. Arbitrer di sini berarti tidak ada hubungan alamiah antara penanda dengan petanda. Contoh lain yang paling representatif mengenai hubungan arbitrer ini adalah mengenai perbedaan bahasa.

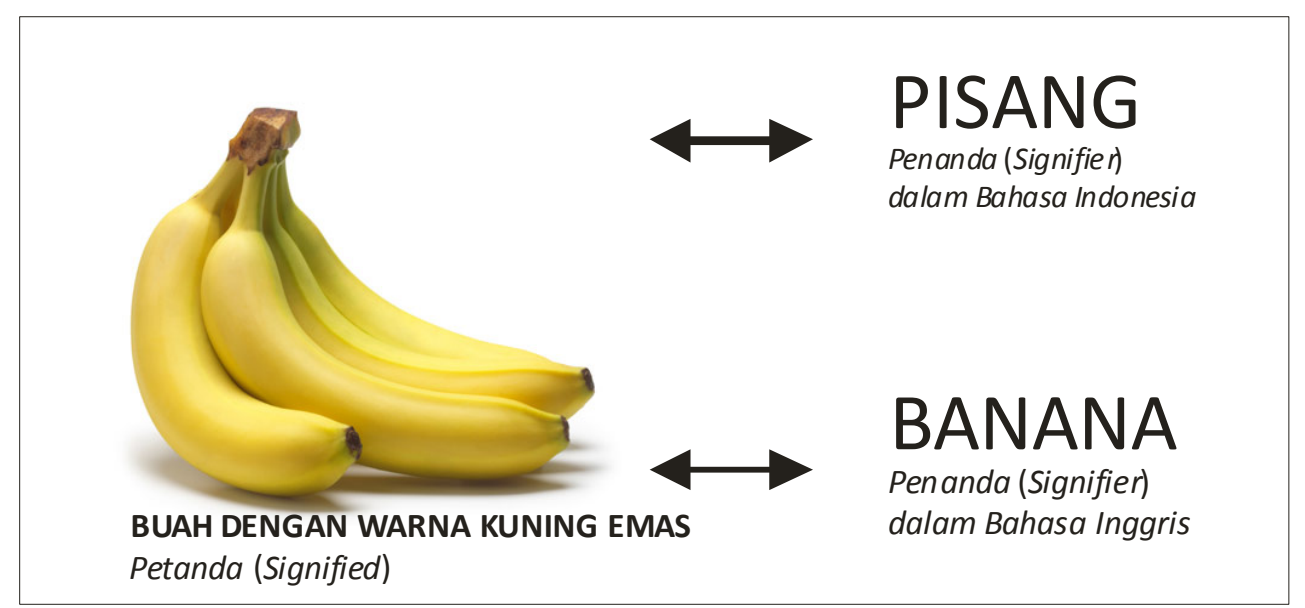

Gambar 1o. Hubungan Arbitrer Penanda dengan Petanda

Apa yang dibayangkan ketika kita mendengar kata pisang, misalnya? Kita pasti membayangkan sebuah buah yang biasanya berwarna kuning emas, atau berwarna hijau, dengan rasa manis dan semi lejar (masam manis), yang berasal dari pohon tertentu yang berbuah hanya sekali. "Pisang", sebagai sebuah kata, huruf, dan bunyi, adalah penanda (signifier); sedangkan buah sebagaimana yang kita bayangkan itu adalah petanda (signified). Hubungan antara "Pisang" dengan "buah sebagaimana yang kita bayangkan tadi" adalah contoh hubungan arbitrer atau semena. Disebut arbitrer, karena orang Amerika atau Inggris, misalnya, menyebut buah yang sama dengan "Banana", sebuah penanda yang beda dengan "Pisang". Itu yang dimaksud tidak ada hubungan alamiah antara penanda dengan petanda. Sebab, melalui konvensi bisa saja kita mengubah penandaan "buah pisang" dengan kata "Kelinci".

\section{PENUTUP}

Analisis semiotik seharusnya memang dipinjam oleh ilmu ekonomi untuk menjelaskan perilaku konsumsi, karena pada dasarnya komoditas yang ada di pasar bisa dianggap sebagai tanda. Dengan mendudukan komoditas sebagai tanda, kita bisa melakukan pendalaman lebih jauh atas fakta-fakta yang tadinya hanya terlihat sederhana, sehingga bisa mendapatkan gambaran kompleks darinya. Dari elaborasi awal 
sebagaimana telah dipaparkan sebelumnya, nampak bahwa perilaku konsumen lebih banyak didorong oleh faktor subyektif daripada obyektif. Subyektivitas perilaku konsumen ini pada akhirnya telah membentuk teori harga yang juga bersifat subyektif, karena perilaku konsumen merupakan dasarnya yang paling menentukan. Persoalannya, sebagaimana telah disinggung serba sedikit di muka, meski dalam kerangka ekonomi mikro bisa dianggap tidak ada masalah dari subyektivitas yang membentuk teori harga, namun secara makro bisa muncul sejumlah persoalan serius yang berpotensi mengacaukan perekonomian. Misalnya, komoditas-komoditas pangan, yang tidak bisa memicu munculnya subyektivitas pada konsumen, akan memiliki nilai tukar yang rendah dibandingkan dengan komoditas yang bisa memicu munculnya subyektivitas. Jika kerangka ekonomi mikro ini dibiarkan tetap bekerja tanpa intervensi, ia bisa mengacaukan keseimbangan makro ekonomi.

\section{DAFTAR PUSTAKA}

Arnold, David. 1996. Pedoman Manajemen Merek. Surabaya: Kentindo Soho. Arrow, Kenneth J. 1973 [1951]. Social Choice and Individual Value, SixthPrinting. New Heaven: Yale University Press.

Banik, Dan (ed.). 2006. Poverty, Politics and Development: Interdisciplinary Perspectives. Bergen: Fogbokforlaget.

Barlow, Maude dan Tony Clarke. 2005. Blue Gold: Perampasan dan Komersialisasi Sumber Daya Air. Jakarta: Gramedia Pustaka Utama.

Bell, Daniel dan Irving Kristol (ed.). 1988. Krisis Teori Ekonomi. Jakarta: $\mathrm{LP}_{3} \mathrm{ES}$.

Berger, Arthur Asa. 200o. Tanda-tanda dalam Kebudayaan Kontemporer. Yogyakarta: Tiara Wacana.

Bernstein, Henry (ed.). 1973. Underdevelopment and Development: The Third World Today. Middlesex: Penguin Books.

Black, R.D. Collison, et.al., (eds.). 1973. The Marginal Revolution in Economics: Interpretation and Evaluation. Durham: Duke University Press.

Brewer, Anthony. 1999. Kajian Kritis Das Kapital Karl Marx. Jakarta: Teplok Press.

Budiman, Kris. 1999. Kosa Semiotika. Yogyakarta: LKIS.

Budiman, Kris. 2003. Semiotika Visual. Yogyakarta: Buku Baik.

Budiman, Kris. 2005. Ikonisitas: Semiotika Sastra dan Seni Visual. Yogyakarta: Buku Baik.

Caldwell, Bruce J. 1994. Beyond Positivism: Economic Methodology in the Twentieth Century. London: Routledge.

Canterbery, E. Ray. 1987. The Making of Economics, Third Edition. California: Wadsworth Publishing. 
Capra, Fritjof. 1977. The Tao of Physics. New York: Bantam Book.

Capra, Fritjof. 1999. Menyatu dengan Semesta: Menyingkap Batas antara Sains dan Spiritualitas. Yogyakarta: Fajar Pustaka.

Case, Karl E. dan Ray C. Fair. 2007. Prinsip-Prinsip Ekonomi, Jilid 1, Edisi Kedelapan. Jakarta: Erlangga.

Castles, Lance. 1982. Tingkah Laku Agama, Politik, dan Ekonomi di Jawa: Industri Rokok Kudus. Jakarta: Sinar Harapan.

Chaney, David. 2004. Lifestyles: Sebuah Pengantar Komprehensif. Yogyakarta: Jalasutra.

Cole, Ken, John Cameron, dan Chris Edwards. 1983. Why Economists Disagree: The Political Economy of Economics. London and New York: Longman.

Corrigan, Peter. 1998. The Sociology of Consumption. London: Sage Publications.

Cullenberg, Stephen, Jack Amariglio, dan David F. Ruccio (ed.). 2001. Postmodernism, Economics and Knowledge. London: Routledge.

Deliarnov. 1995. Perkembangan Pemikiran Ekonomi. Jakarta: Raja Grafindo.

Deliarnov. 2006. Ekonomi Politik. Jakarta: Erlangga.

Dua, Mikhael. 2008. Filsafat Ekonomi: Upaya Mencari Kesejahteraan Bersama. Yogyakarta: Kanisius.

Elster, Jon. 200o. Marxisme: Analisis Kritis. Jakarta: Prestasi Pustakaraya.

Frohlich, Norman dan Joe A. Oppenheimer. 1984. Politik Ekonomi Modern. Jakarta: Bina Aksara.

Galbraith, John Kenneth. 1958. The Affluent Society. New York: Mentor Books.

Gunawan, Anton H., Arianto Patunru, dan Ali Winoto, 1997, "Perkembangan Teori Ekonomi Makro: Kembali ke Konsep Dasar", dalam Moh. Arsjad Anwar, Aris Ananta, dan Ari Kuncoro (ed.), Pembangunan Nasional: Teori, Kebijakan, dan Pelaksanaan-Widjojo Nitisastro 70 Tahun (Jakarta: Fakultas Ekonomi UI).

Heilbroner, Robert L. 1962. The Worldly Philosophers: The Lives, Times and Ideas of the Great Economic Thinkers. New York: Simon and Schuster.

Hirshleifer, Jack. 1985. Teori Harga dan Penerapannya, Edisi Ketiga. Jakarta: Erlangga.

Kartajaya, Hermawan, Yuswohady, dkk. 2005. Positioning, Diferensiasi, dan Brand. Jakarta: Gramedia.

Kasali, Rhenald. 2003. Membidik Pasar Indonesia: Segmentasi, Targeting, dan Positioning. Jakarta: Gramedia.

Katouzian, Homa. 1980. Ideology and Method in Economics. London: MacMillan.

Keraf, Sonny. 1996. Pasar Bebas, Keadilan, dan Peran Pemerintah: Telaah Atas Etika Politik Ekonomi Adam Smith. Yogyakarta: Kanisius. 
Keraf, Sonny. 1998. Hukum Kodrat dan Teori Hak Milik Pribadi. Yogyakarta: Kanisius.

Kotler, Philip, 200o, "Memetakan Pasar di Masa Depan", dalam Rowan Gibson (ed.), Rethinking The Future (Jakarta: Gramedia, 200o).

Kridalaksana, Harimurti. 2005. Mongin-Ferdinand de Saussure: Peletak Dasar Strukturalisme dan Linguistik Modern. Jakarta: Yayasan Obor Indonesia.

Levitt, Steven D. dan Stephen J. Dubner. 2006. Freakonomics. Yogyakarta: Penerbit Baca!.

Lury, Celia. 1998. Budaya Konsumen. Jakarta: Yayasan Obor Indonesia.

Mankiw, N. Gregory. 2006. Principles of Economics (Pengantar Ekonomi Mikro), Edisi Ketiga. Jakarta: Salemba Empat.

Marshall, Alfred. 1953 [1891]. Principles of Economics, Eight Edition. New York: The MacMillan Company.

Marx, Karl. 1959 [1867]. Capital: A Critical Analysis of Capitalist Production, Volume One. Moscow: Foreign Languages Publishing House.

McEvoy, J.P. dan Oscar Zarate. 1997. Mengenal Teori Kuantum. Bandung: Mizan.

Mehmet, Ozay. 1999. Westernizing The Third World: The Eurocentricity of Economic Development Theories, Second Edition. London: Routledge.

Mubyarto. 1995. Pengantar Ekonomi Pertanian, Edisi Ketiga. Jakarta: LP 3 ES.

Myrdal, Gunnar. 1970. Objectivity in Social Research. London: Gerald Duckworth \& Co.

Nataatmadja, Hidayat. 2007. Melampaui Mitos E Logos: Pemikiran ke Arah Ekonomi-Baru. Yogyakarta: LANSKAP.

Nelson, Robert H. 2001. Economics as Religion: From Samuelson to Chicago and Beyond. Pennsylvania: The Pennsylvania State University Press.

Nicholson, Walter. 2002. Mikroekonomi Intermediate dan Aplikasinya, Edisi Kedelapan. Jakarta: Erlangga.

Nugroho, Tarli, dkk. 2008. Ensiklopedi Ilmu Pengetahuan Sosial. Yogyakarta: Pustaka Insan Madani.

Nugroho, Tarli. 2003. Potret Ekonom sebagai Si Malinkundang: Sebuah Pandangan Awal tentang Ekonomi-Politik Indonesia. Yogyakarta: LANSKAP.

Nugroho, Tarli. 20o8. Pusat Perbelanjaan sebagai Parasit Ekonomi. Yogyakarta: LANSKAP.

Peter, J. Paul dan Jerry C. Olson. 200o. Consumer Behaviour: Perilaku Konsumen dan Strategi Pemasaran, Jilid Dua, Edisi Keempat. Jakarta: Erlangga.

Piliang, Yasraf Amir. 2004. Hipersemiotika: Tafsir Cultural Studies atas Matinya Makna. Yogyakarta: Jalasutra.

Prabowo, Dibyo. 1983. Kegagalan Pasar: Analisa tentang Eksternalitas dan Barang Kolektif. Yogyakarta: BPFE. 
Quart, Alissa. 2008. Belanja Sampai Mati: Ancaman Komersialisasi Remaja Masa Kini. Yogyakarta: Resist Book.

Quart, Alissa. 2008. Belanja Sampai Mati: Ancaman Komersialisasi Remaja Masa Kini. Yogyakarta: Resist Book.

Rahman, Abdul dan Ari Satriyo Wibowo, dkk. 1996. Merek-Merek Terpopuler di Indonesia. Jakarta: Elexmedia Komputindo.

Rahman, Abdul dan Ari Satriyo Wibowo, dkk. 1996. Merek-Merek Terpopuler di Indonesia. Jakarta: Elexmedia Komputindo.

Ries, Al dan Jack Trout. 1988. Mengatur Posisi. Jakarta: Erlangga.

Ries, Al dan Jack Trout. 1988. Mengatur Posisi. Jakarta: Erlangga.

Ries, Al dan Jack Trout. 2001. Positioning: The Battle for Your Mind. Jakarta: Salemba Empat.

Ries, Al dan Jack Trout. 2001. Positioning: The Battle for Your Mind. Jakarta: Salemba Empat.

Ritzer, George. 2004. Teori Sosial Postmodern. Yogyakarta: Kreasi Wacana. Ritzer, George. 2004. Teori Sosial Postmodern. Yogyakarta: Kreasi Wacana. Robinson, Joan. 1968. Economic Philosophy. Middlesex, UK: Pelican Book. Robinson, Joan. 1968. Economic Philosophy. Middlesex, UK: Pelican Book.

Samuelson, Paul A. dan William D. Nordhaus. 1995. Mikroekonomi, Edisi Keempatbelas. Jakarta: Erlangga.

Sastradipoera, Komaruddin. 2007. Sejarah Pemikiran Ekonomi: Suatu Pengantar Teori dan Kebijaksanaan Ekonomi. Bandung: Kappa-Sigma.

Saussure, Ferdinand de. 1996. Pengantar Linguistik Umum, Cetakan Ketiga. Yogyakarta: Gadjah Mada University Press.

Schumacher, EF. 1975. Small is Beautiful: Economics as if People Mattered. New York: Perennial Library.

Schumpeter, Joseph A. 1955. History of Economic Analysis. London: George Allen \& Unwin.

Schumpeter, Joseph A. 1963. Sepuluh Sarjana Ekonomi Terkemuka: Dari Marx sampai Keynes. Jakarta: Bhratara.

Skousen, Mark. 2001. The Making of Modern Economics: The Lives and Ideas of the Great Thinkers. New York: M.E. Sharpe.

Soros, George. 2007. Open Society: Reforming Global Capitalism. Jakarta: Yayasan Obor Indonesia.

Sunardi, St. 2004. Semiotika Negativa. Yogyakarta: Buku Baik.

Sutherland, Max dan Alice K. Sylvester. 2005. Advertising and the Mind of the Consumer. Jakarta: Penerbit PPM.

Syamsurizal, Dick. 1992. Branding: Alternatif Alat Pemasaran Potensial. Bandung: Humaniora Utama Press.

Townsend, Harry (ed.). 1973. Price Theory: Selected Readings. London: Penguin.

Varian, Hal R. 1996. Intermediate Microeconomics: A Modern Approach, Fourth Edition. New York: W.W. Norton. 
Veblen, Thorstein. 1957 [1899]. The Theory of the Leisure Class: An Economic Study of Institutions. New York: Mentor Book.

Ward, Benjamin. 1972. What's Wrong with Economics?. New York: Basic Books.

Wibowo, Ari Satriyo, Ventura Elisawati, dan Hermawan Kartajaya. 2001. 36 Kasus Pemasaran Asli Indonesia. Jakarta: Elex Media Komputindo.

Winardi. 1990a. Ilmu Ekonomi dan Aspek-aspek Metodologisnya. Jakarta: Rineka Cipta.

Winardi. 199ob. Pengantar Ekonomi Mikro (Teori Harga). Bandung: Mandar Maju.

Wirartha, I Made. 20o6. Metodologi Penelitian Sosial Ekonomi. Yogyakarta: Penerbit Andi.

Zimmerman, L.J. 1955. Sedjarah Pendapat-Pendapat tentang Ekonomi (Geschiedenis van het Economisch Denken). Bandung: W. van Hoeve. 